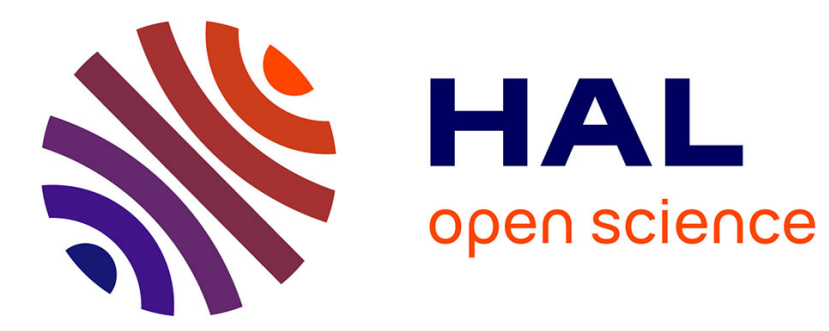

\title{
Design theories, creativity and innovation
}

Pascal Le Masson, Armand Hatchuel, Benoit Weil

\section{To cite this version:}

Pascal Le Masson, Armand Hatchuel, Benoit Weil. Design theories, creativity and innovation. The Elgar Companion to Innovation and Knowledge Creation, 2017. hal-01619983

\section{HAL Id: hal-01619983 \\ https: / hal-mines-paristech.archives-ouvertes.fr/hal-01619983}

Submitted on 20 Oct 2017

HAL is a multi-disciplinary open access archive for the deposit and dissemination of scientific research documents, whether they are published or not. The documents may come from teaching and research institutions in France or abroad, or from public or private research centers.
L'archive ouverte pluridisciplinaire HAL, est destinée au dépôt et à la diffusion de documents scientifiques de niveau recherche, publiés ou non, émanant des établissements d'enseignement et de recherche français ou étrangers, des laboratoires publics ou privés. 
Pascal Le Masson, Armand Hatchuel, Benoit Weil

MINES ParisTech, Chair Design Theory and Methods for Innovation, Center for Management Science, 60 boulevard Saint-Michel, F- 75272 Paris cedex 06, France

\section{Aknowledgement:}

This paper was initially published in Creativity and Innovation Management Journal, 20, (4), pp. 217-237. We warmly thank the editors of the journal and Wiley Journals Development Editor for their acceptance. 


\title{
DESIGN THEORIES: INCREASING GENERATIVITY TO ADDRESS THE ISSUES OF CREATIVITY AND INNOVATION
}

\begin{abstract}
:
In this paper, we analyze the relationship between creativity issues and design theory. Although these two notions seemingly correspond to different academic fields (psychology, cognitive science and management for creativity; engineering science and logic for design theory), they appear to be deeply related when it comes to design methods and management. Analyzing three historical moments in design theorybuilding (the 1850s, with the ratio method for industrial upgrading in Germany; the $20^{\text {th }}$ century with systematic design and the 1920s with the Bauhaus theory), we point to the dialectical interplay that links creativity and design theory, structured around the notion of "fixation effect": creativity identifies fixation effects, which become the targets of new design theories; design theories invent models of thought to overcome them; and, in turn, these design theories can also create new fixation effects that will then be designated by creativity studies. This dialectical interplay leads to regular inventions of new ways of managing design, ie new ways of managing knowledge, processes and organizations for design activities. We use this framework to analyze recent trends in creativity and design theories.
\end{abstract}

\section{Introduction: design methods and creativity issues in the light of design theories.}

In this paper, we analyze the relationship between creativity issues and design theory from an historical perspective. Although these two notions seemingly correspond to different academic fields (psychology, cognitive science and management for creativity; engineering science and logic for design theory), they appear to be deeply related when it comes to design methods and design management. This relationship is quite complex. For instance, in his presidential address of the Design Research Society in 2006 (Cross 2006), Cross underlined the coincidence between the renewal of design methods, based on problem-solving, and creativity issues related to creative problem-solving in the 1950s and 1960s in the US (Gordon 1961; Osborn 1953; Alexander 1964; Archer 1965; Simon 1969). But he also noted that design methods were strongly criticized in the 1970s, even by some of their former supporters (Alexander 1971), because they could not address "wicked" problems (Rittel and Webber 1972). This raises the question of whether design methods and theory address creativity issues or whether creativity issues find fault with design methods.

The design professions answer this question in different ways. Ulrich and Eppinger (Ulrich and Eppinger 2008) define design through its two main professions ("design ... includes engineering design (mechanical, electrical, software, etc.) and industrial design (aesthetics, ergonomics user interfaces)." (p. 3)). Strangely enough, the two professions address creativity issues in different manners. Engineering design, as defined in the reference manuals for teaching design to engineers all over the world (Roth 1982; 
Rodenacker 1970; Pahl and Beitz 1977, 2006; Ulrich and Eppinger 2008; Pugh 1991; French 1999), aims to propose convergent thinking methods for developing new products, not relying on chance but based on scientific knowledge and design rules. It faces creativity issues in complex problem solving, through expertise and knowledge acquisition, through well-planned design processes (eg stage-gate, NPD) and sophisticated organizations (see engineering departments, marketing departments, research labs, etc.). Recent critics have also underlined that some innovation issues require engineering design practices to evolve (Eppinger 2011). Industrial design insists on the risk of fixation due to usual skills and representations of the objects, it favours out-of-the-box thinking, new visions, brainstorming and the acquisition of knowledge from users. It strives to address contemporary creativity issues such as the creation of meaning (Verganti 2008).

These examples show that there are a variety of design methods and that they address creativity issues in different ways. In this paper, we study this relationship between design methods and creativity issues to see whether it is a coincidence or whether there is a specific logic behind it. Clarifying this issue might provide a better understanding of contemporary issues in creativity and how they are related to recent results in research on design theory and methods. Confronted with the variety of design methods and creativity issues, we made two methodological choices:

- First, we focus on design theories. Recent literature reviews on product design (see for instance the special issue of the Journal of Product Innovation Management in May 2011, (Swan and Luchs 2011)) have underlined the difficulty in finding a consensual definition. We therefore focus more specifically on design theories, ie models of design reasoning, to help address the variety of definitions and still have a rigorous means of controlling the consistency of the methods. In this perspective, recent advances in the academic community of engineering design (eg the Design Society), and more specifically in research on design theory, have shown interesting results regarding the relationship between design theory and creativity issues. For instance, it has been shown that past design theories (in particular Simon's design theory based on problem-solving) could not tackle some creativity issues (Dorst 2006; Hatchuel 2002); and some authors have proposed new design theories which explicitly address specific creativity issues (see for instance (Shai et al. 2009)). There may therefore be a deep link between design theories, considered as models of design reasoning, and creativity issues. We will look for the models of design reasoning that underlie the methods of engineering design (or the methods of industrial design). This will enable us to analyze how these methods help designers to address some creativity issues and fail to address others. We identify three main notions:

○ Design theory, by which we mean a formal model of design reasoning.

- This model of design reasoning inspires forms of organizing collective design activities. We will characterize these forms through three features: the role of knowledge in design, the design process and the design organization.

- These forms of collective design help achieve a certain level of performance in terms of addressing creativity issues. 
- Second, we take a historical perspective. In this case too, research carried out by the engineering design community is inspiring. For instance (Hatchuel et al. 2011a) have shown that recent design theories form a consistent body of knowledge that tends to increase the creativity of design. This result seems to confirm our belief that there are historical dynamics linking creativity issues and the development of new models of design reasoning. Hence our research question: we investigate the assumption that new models of design reasoning emerged to address new creativity issues; that the models that led to widespread methods also helped to better address these creativity issues; and that these models and related methods were finally criticized for not addressing new, emerging creativity issues. Creativity is a relatively recent academic notion (a large number of studies on creativity were launched in the field of psychology in the 1950s following the presidential address by a famous American psychologist, Joy Paul Guilford, who defined creativity as a form of intelligence to be distinguished from that measured by IQ (Guilford 1950). But based on recent results in this academic field, one can identify creativity issues as the issues that limit creativity. Recent studies have shown that they can be analyzed as different forms of fixations (see in particular the synthesis in (Hatchuel et al. 2011b)). A study of these fixations helps to recognize creativity issues that were faced in the last two centuries.

We give a schematic summary of these notions in Figure 1 below.

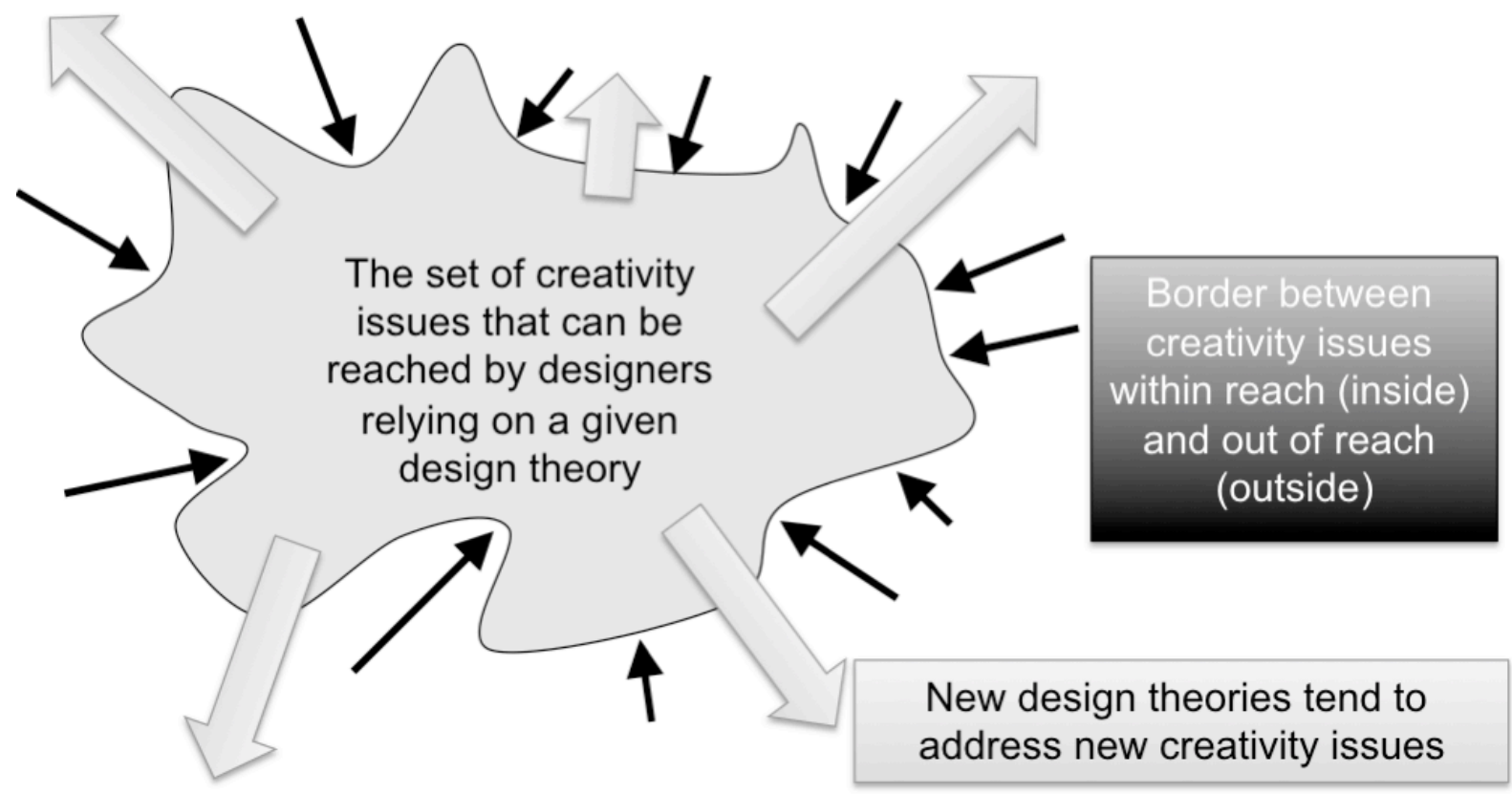

Figure 1: a schematic summary of the main notions for analyzing the interplay between creativity issues and design theory

There is therefore neither intrinsic opposition nor natural convergence between design theory and creativity issues. Our intuition is that of a "dialogue" between them. At certain historical moments, this dialogue enlightens the limits of collective designers relying on a design theory and confronted with new, emerging creativity issues. This can lead to the emergence of new design theories and new forms of collective design 
activities. Hence design theory and creativity issues may be two ways -one normative, the other critical- of dealing with collective design activities. Their interplay may lead to the invention of specific forms of collective design.

To investigate the issue of the relationship between creativity issues and design theory, we revisit three historical moments in the building of design theory. First, the ratio method, ie the design theory used for industrial upgrading in Germany in the 19th century; second, systematic design, ie the theory used for organizing R\&D departments throughout the world from 1950 onwards; and third, the Bauhaus methods and theory of the 1920s, which were used in a large number of design schools around the world. For each period, we study the creativity issues addressed, the formal model of design reasoning underlying it, the types of design capabilities inspired by the design theory and the type of outcome expected (part 2). In a third part, we point to the interplay linking creativity issues and design theory, structured around the notion of "fixation effect": creativity identifies fixation effects, which become the targets of new design theories; design theories invent models of thought to overcome them; and, in turn, these new design theories can also create new fixation effects that will then be designated by creativity studies. This dialectical interplay leads to regular inventions of new ways of managing design, ie new ways of managing knowledge, processes and organizations for addressing specific design issues.

\section{Part 1: an analytical framework for learning from the history of creativity issues and design theories}

\section{I.A. Three types of tensions between design methods and creativity issues}

The literature distinguishes between three facets of the complex relationship between design methods and creativity issues:

- How to deal with knowledge in design. Engineering design methods underline the importance of relying on knowledge and competences. Acquiring and managing knowledge is one of the key issues in these methods. This has led to forms of evaluation of R\&D. For instance, the notion of absorptive capacity characterizes the contribution of research to the innovation process as the capacity to absorb relevant external knowledge (Cohen and Levinthal 1990; Lane et al. 2006). Conversely, studies in creativity have shown how knowledge can create "fixation" (Jansson and Smith 1991; Smith et al. 1993) and how it can become a core rigidity instead of a core capability (Leonard-Barton 1992). Hence, knowledge can support but it can also limit design capabilities, and it is not always easy to devise compromises (Weisberg 1999; Basadur and Gelade 2006).

- Should the design process be divergent or convergent? Creativity studies insist on the necessity to diverge, although some authors do admit that convergence is also important, often advocating initial divergence followed by unavoidable convergence (Eris 2004; Dym et al. 2005; Cropley 2006). Conversely, literature on product development processes favours convergent thinking, even if divergence can also be required from time to time (eg diverge at the fuzzy front end (Koen et al. 2001; Reid and De Brentani 2004); or diverge during the processes, in flexible product development (Kelley 2009; MacCormack et al. 2001)). 
- Is the design organization based on strong leadership and well-administered projects or more on autonomous, creative teams? What is the form of design work division? Since Osborn invented brainstorming at the advertising agency BBDO (Osborn 1957), creativity studies tend to analyze teams' creativity in organizations (Hargadon and Sutton 1997; Paulus and Brown 2007; Paulus and Yang 2000). Working on how creativity is organized, Amabile showed how project structures and administration were poorly adapted to creative teams (Amabile et al. 1996; Amabile 1998). Conversely, engineering design methods tend to focus on how engineering design departments and marketing departments are organized and on their relationship to research labs. They insist on the structures, methods and administration of engineering design. Even in cases of radical innovation, requiring creativity from the teams, authors have shown that rigorous management is required, for instance for managing the unknown with well-balanced, sequential and parallel learning (Loch et al. 2006), managing concept shifts based on memorisation and modularisation (Seidel 2007) or managing major innovation with a "systems approach" (O'Connor 2008). Some authors have called for a combination of creative and non-creative teams in ambidextrous organizations (Tushman and O'Reilly III 1996), but empirical studies have stressed the limits of such simplifying compromises (Brown and Eisenhardt 1997).

\section{I.B. Beyond compromises: the dialectical interplay between creative issues and design theories?}

The relationship between design methods and creativity issues appears to be made of compromises: in knowledge, to balance fixation and non-fixation; between convergence and divergence in design processes; and between control and autonomy in design organization. Compromises can find tradeoffs between the extremes, but two clues suggest that some design theories and methods apparently invented compromises that helped to keep the advantages of the two extremes, overcoming the dilemmas by inventing combinations such as knowledge for unfixing, divergence for convergence, and design control for increased creative autonomy:

1) One might think that creativity has no place in engineering design but this is far from true. Creativity was an historical issue for the theorists of systematic design, as underlined by Wolfgang König (König 1999). For instance, in the 1850s, the great ancestor of German systematics, Ferdinand Redtenbacher, proposed a proto-version intended to make designers (the technicians of that time), "more innovative" (Redtenbacher 1852a). The first teacher of elaborate "systematics", the Russian professor Peter Klimentitsch von Engelmeyer, called his method a "theory of creative work" (Engelmeyer 1895). As analyzed by Mathias Heyman (Heymann 2005), in the 1970s there were many debates in the German systematics community to clarify how far systematic design was already addressing the creativity issue. More recently, Udo Lindeman, former president of the Design Society, has shown how classical systematic design took into account the creativity required from design engineers (Lindemann 2011). This means that past design theories undoubtedly "invented" ways to manage knowledge, processes and organization for dealing with creativity issues. They were able to use knowledge and still be unfixed, to converge and diverge, and to 
control while preserving creativity in teams. This also underlines the need for a more precise analysis of the theoretical roots of design methods.

2) In certain fields such as industrial design, the design methods and creativity issues are not in tension but, on the contrary, industrial design methods are said to match creativity issues. Could a design theory for industrial design propose ways of addressing opposites, ie: using knowledge without being fixed, diverging and converging, and organizing controlled autonomy in design?

We reinterpret the above-mentioned tensions in a more "historical" perspective, based on the theoretical roots of design methods. At certain moments in time, the incumbent design methods are considered too limited, with regard to societal issues, new collective imagination etc. Creativity issues then address the limits of past design theories and methods. As a result of this critique, new design theories are proposed to "stretch" design capacities to overcome fixations. They propose new frameworks with new ways of dealing with knowledge, processes and organizations, with a view to addressing the newly-identified creativity issues. Finally, they enable new types of innovation output. This is our main research hypothesis: there may be "dialectic" interplay between creativity issues and design theories, which leads to the regular invention of new forms of design and new types of innovation output. Over time, this dialectical process has generated different ways of dealing with knowledge, different forms of design processes and design organizations, to address different types of creativity issues.

\section{I.C. Method: analytical framework to study historical cases}

To study this hypothesis, we investigated three historical moments in the creation of design theory to analyze whether and in what manner they dealt with creativity issues and what the formal proposals tell us about knowledge in design, design process and organization.

Recent works have shown the interest of an historical approach to management science, particularly in the realm of strategic management (Zan 2005). Authors have underlined the pertinence of the approach for studying the interaction between management theories and historical forms of collective action (Hatchuel and Glise 2003). We decided that it was a relevant method for our particular study because it enabled us to analyze the dynamic interplay between creativity issues, the emergence of design theories and their effects in terms of design methods and design outputs. Methodologically speaking, we focused on specific "tipping moments" when new design theories emerged rather than covering very long periods of time.

Case selection. 1- We selected three theories that were widely diffused: the ratio method was taught in a large majority of German Technische Hochschule from the 1850s to the early $20^{\text {th }}$ century; systematic design still serves as the basis for the main courses in engineering design; and the Bauhaus theories have inspired industrial design teaching since their creation in the 1920s. 2- We chose theories that are related to two contrasted professions in design, two from engineering and one from industrial design. 3- We selected theories on which we had sufficient material to address theoretical aspects (books, papers, etc.), as well as the methods, the industrial context of the time and the innovation outputs related to these methods (handbooks, testimonies, historical monographs, work by historians, etc.). It is interesting to note that the main historical 
sources were not translated into English, which explains why several elements of this history are hardly known in the English literature.

In each case, we follow the same analytical framework:

- We characterize the creativity issues that the theory intended to address and the kind of "fixations" to be overcome.

- We analyze the principles of the theory (with a brief presentation of some illustrations) and how it helps to address the creativity issues and to overcome the fixation effects. In particular, we underline how it leads to new ways of dealing with knowledge in design, design processes and organization, ie how it leads to the proposal of new design capabilities.

- Finally, we analyze the types of innovation expected from the theory and the type of fixation that it might cause.

\section{Part 2: historical cases of inventions of design theories. German engineering design and Bauhaus industrial design}

\section{II.A. The method of ratios}

\section{II.A.1- Fixed by existing objects}

The first theory (or method) of engineering design is attributed to Redtenbacher (König 1999; Redtenbacher 1852a). In the 1840s, this Swiss engineer and professor, who taught machine construction at the newly created Technische Hochschule in Karlsruhe, developed an original course based on a new method called the "method of ratios". In very close relationship to the industry and the machines of his time, he noted that technicians-designers rebuilt the same machine, whatever the context (environment, use of the machine, budget, available material, etc.). He was neither the first nor the only one to make this observation. Since Diderot, several "technologs", in particular in the French engineering and science education system, had also seen the limits of technicians who were unable to innovate using the available technical knowledge. Two types of causes were identified. The French scientists and professors believed that the rules themselves had to be improved, through science, experiments and the diffusion of more accurate knowledge. In the German professor's view, the quality of the knowledge was indeed necessary, but not enough. He wrote in his preface to Resultate für den Maschinenbau (Redtenbacher 1852b): "With the principles of mechanics, machines cannot be invented, because to do so, one also requires precise knowledge of the mechanical process for which the machine is to be used. With the principles of mechanics, sketches of machines cannot be made, because a sense of composition, arrangement and forming is also required. With the principles of mechanics, no machines can be made as this requires practical knowledge of the materials to be worked and experience in handling tools and auxiliary equipment. With the principles of mechanics, one cannot manage an industrial business, as this requires a strong personality and knowledge of commercial affairs". For Redtenbacher, the constant replication of a limited number of known objects was also due to the limited capacities of the technician-designer to make use of knowledge for creating new objects. 
The ratio method aimed precisely to address these two fixations: 1) it proposed synthetic models of existing objects, so-called "object models" (in a relatively classical mode, it created knowledge on existing objects (cf. laws of mechanics)) and 2) (and this is the most original part) it proposed a method to make use of these synthetic models to design partially unknown objects. It is interesting to note how careful Redtenbacher was, in his classes and his manuals, to separate the part where he built "complete theories" on existing objects from the part where he proposed an approach for gradually determining unknown objects. The classical teaching in mechanics inferred that the model of existing things was sufficient for designing, as if the model for designing a new object could be easily deduced from the models of existing ones. After modeling objects, Redtenbacher added a second part based on a "generative model", which is the conceptual "twin" of the object model. The surprise was that this "twin" had a very different structure from that of the object model. The object model established relationships between the object's attributes, whereas the method of ratios clarified the order in which the attributes that determine the object should be added. Beyond the method, Redtenbacher claimed to propose "principles for machine design" (Prinzipien für den Maschinenbau). He explained that he was not only providing a theory of existing objects but also a theory for constructing still partially unknown objects using knowns. The principles at the root of the method of ratios constitute a parametric design theory: in Redenbacher's terms, machine design consists in instantiating a parametric model of the object taking into account context-specific data. It was one of the first theories to propose rules for organizing the exploration of the unknown in relation to the known.

These principles sought to avoid overlooking solutions and the too systematic use of knowns, when known solutions were reused although they were in fact ill-adapted. They also obliged designers to stay a little longer in the domain of the unknown, at higher levels of abstraction than those used to make physical models, to imagine alternatives to what was suggested by intuition and past experience.

\section{II.A.2- An illustration}

We can illustrate how the method works by looking at a simple case: designing waterwheels (Redtenbacher 1858). In the first part of the book (Chapters 1 to 3), Redtenbacher made a state of the art review of wheels and existing theories, gradually formulating a series of "equations of effects" relating to the performance and dimensions of waterwheels. He based his arguments on work by Poncelet (Poncelet 1827), Navier and Morin, but also by Smeaton (although his experiments dated back to 1759) (Smeaton 1810), and also gave the results of his own experiments. 


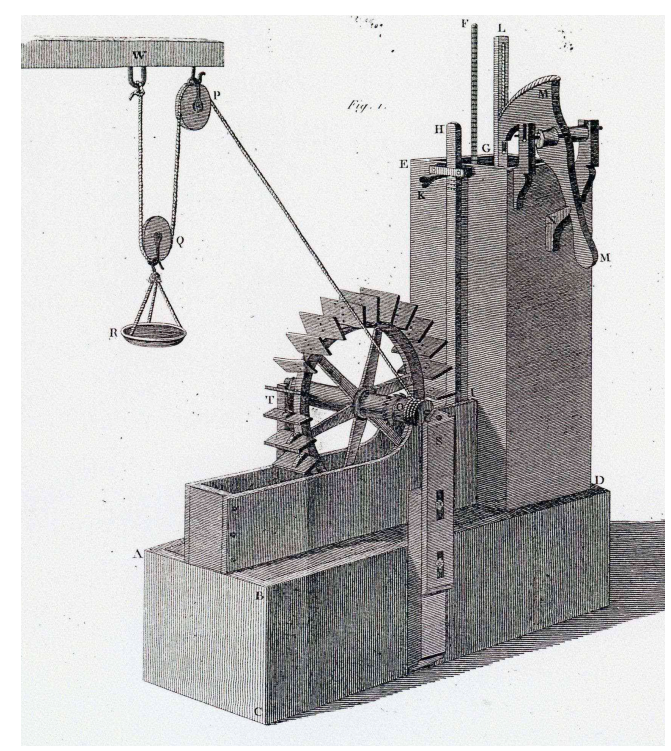

Figure 2: Smeaton's experimental device (1759)

However, these studies did not look at any particular features of the wheel or its immediate environment. For example, there were no equations for the size of the wheel, its diameter and width, nothing about choosing blades or buckets, about the number of buckets or their shape, about the depth at which the wheel should plunge into the water, about care to be taken in assembly and in controlling leakage. All these limitations meant that designers could not use the scientific results that had been obtained by then. This is why, still in the first part of his works, Redtenbacher completed the state of the art review with comprehensive models of existing machinery, grouped by main types.

Once he had built up these major descriptive models, Redtenbacher went on to the second, most original part of the book: the method of ratios. Chapter 4 described the series of rules to be used to assess "the specific forms and dimensions on which the effect of the wheel preferentially depends, in the conditions of perfect constructions." The method began by following the main stages of a fictive dialogue between a designerentrepreneur and a client. According to Redtenbacher, the first question concerned the budget that the client was prepared to devote to the structure as, depending on the answer, the designer could choose between a wooden and a metal wheel, the performance and size equations being very different for the two options. Once the material chosen, two other questions had to be answered: the height of fall of the water flow and the usable flow (or the expected power generated on the shaft, which comes to the same thing). The designer then used a chart (see graph below) to help choose the best type of wheel depending on the height and the flow. At this stage, the method enabled the designer to choose a class of wheels by evaluating the expected performance, but without having to specify all the dimensions. 


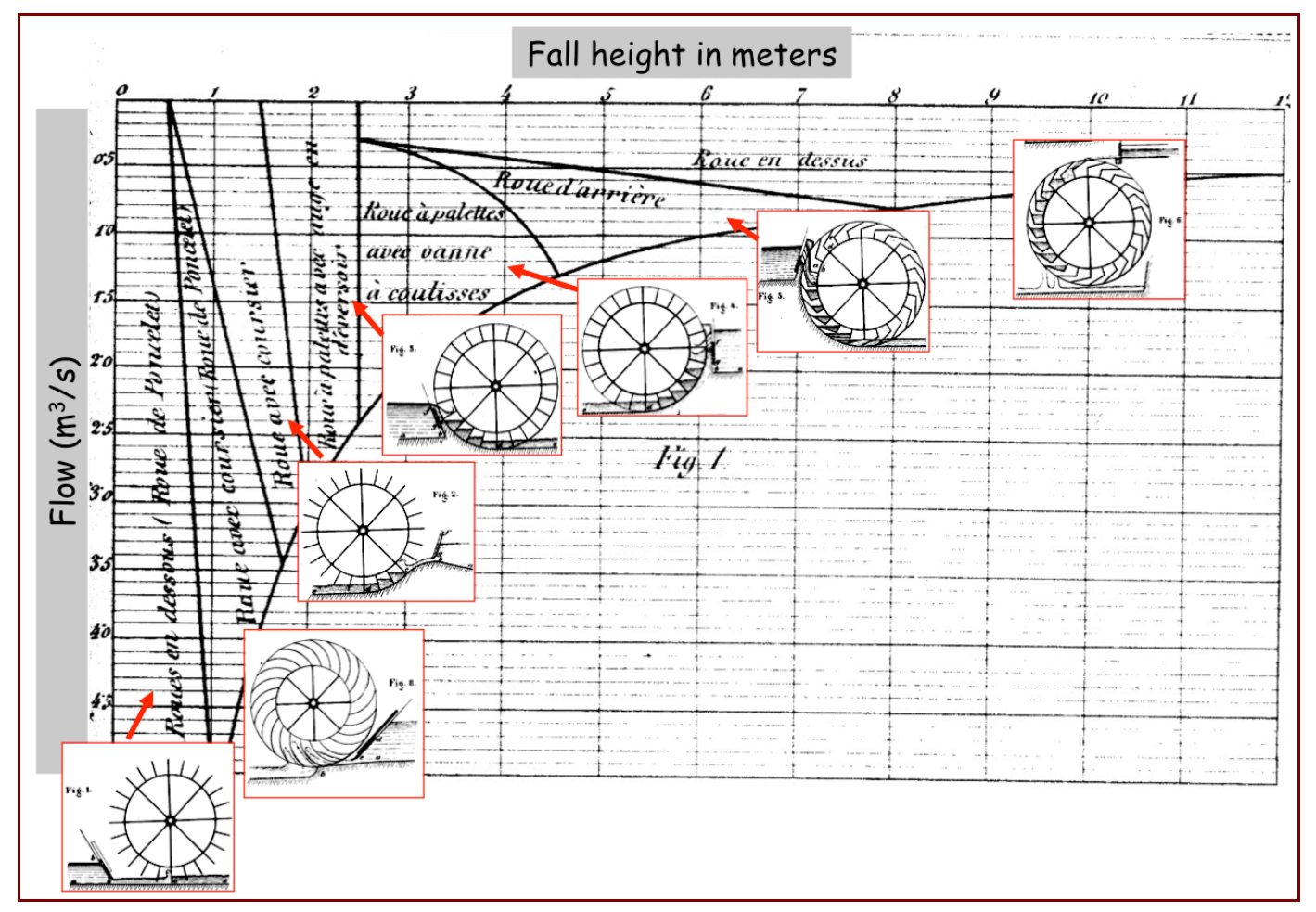

Figure 3: Chart for selecting types of waterwheel depending on conditions of use

At that time, this was the most critical part of the reasoning for Redtenbacher, as he had observed that most wheels were poorly adapted to their environment.

The second phase in selecting the dimensions consisted in specifying step by step, in a specific order given by the method, all the parts of the construction, following methods of calculation or plans (proposed in the book) which were rather like patterns. The plans were dimensionless and also showed the ratios between the parts depending on a fixed known entity. He then specified the linkages and the level of precision for the entire construction. The last part concerned what could be called "finalisation": Redtenbacher recalled the formulas for theoretical performance and the measurement technique for real performance, inviting designers to compare the performance measured on the construction with the theoretical performance and indicating how to improve the real performance of nearly completed wheels.

\section{II.A.3- Success of the method - types of innovation}

Redtenbacher's theory was one of the first design theories for the world of machines. The method of ratios was not new; Redtenbacher himself recognized that it came from architecture. Wolfgang König pointed out that before Redtenbacher a similar method had been used by English and German mechanics (König 1999) (p. 24). But König also noted that Redtenbacher deserves the credit for introducing the method on such a wide scale, in polytechnic schools and in industrial practices. There were several successive editions of Redtenbacher's works and they were also translated into French. Up to the 1880s, all the manuals and technical handbooks were based on the method of ratios. Moreover, despite the criticism it received at the end of the century, it was still widely used during the following century. There was wide recognition of Redtenbacher's 
contribution among German engineers in the $19^{\text {th }}$ century, as proved by the many tributes paid to him by professors and students

What was the impact of the method in terms of innovation? It is striking that Redtenbacher made very few claims in this respect: the method served to treat problems in which the designer was already very knowledgeable, as the machine's arrangement was already known in terms of its objectives and its order. Many of the machines covered in his books were not the high technology machines of the time. In 1843 , when Watt's steam engine was already over 60 years old, Redtenbacher was still writing about waterwheels!

But we know how misleading the term "innovation" can be. As far as Redtenbacher was concerned, the challenge was industrial upgrading. The idea was to provide, as quickly as possible, a cheap, efficient source of energy suited to the needs of the rapidly expanding industries of the time (particularly the textile industry). It was not even a question of making a "perfect" waterwheel (contrary to Poncelet, whose aim was to find a wheel that transmitted the entire momentum of the water flow to the shaft); Redtenbacher sought to provide tools for making a variety of different wheels that were well suited to their environments.

\section{II.A.4- Redtenbacher's design principles at the root of new forms of collective design}

Although it is not an organizational model, the ratio method tells us a lot about knowledge for design, design processes and organization (for the $19^{\text {th }}$ century).

Regarding knowledge: to avoid the fixation effect of existing objects, the ratio method provided models of existing objects (object models) (as Diderot's encyclopedia did) and knowledge on how to use that knowledge at the right moment, depending on the context, ie a kind of "context-sensitive" algorithm. This has a clear "unfixing" effect in the sense that technical designers were able to design very different objects (based on the same object model) and objects that were adapted to the context.

The ratio method also structured a specific "convergent \& divergent" process. Selfevidently, the method ensured convergence towards one acceptable solution. But it also prevented the designer from converging too fast. The method identified precisely, for each type of object, the moment in the design process when it was possible and fruitful to diverge and the type of investigation that was relevant: divergence on material, guided by the customer's budget, divergence on the type of wheel, based on the chart, and divergence in finalisation, based on the theoretical performance target.

One can note that the ratio method corresponds to specific forms of dividing work in design. It leads to distinguish between two roles in the design organizations: a "rulemaker" (like Redtenbacher himself) design rules (ratios,...) to a technician-designer who is a "rule-user". The rule-maker exert leadership, choosing the product families and defining the areas of freedom to be delegated to the rule-user, whereas the latter exercise creativity, within these areas of divergent thinking. 
This very simple example of design theory illustrates how a design theory was developed to counterbalance some forms of fixation and supported ways of dealing with knowledge, process and organization to invent a new form of innovation management.

\section{II.B. Systematic Design}

\section{II.B.1- Fixed by existing rules and machine elements}

We shall now analyze a more sophisticated design theory, called systematic design (SD). This method is very well known, is taught in several reference handbooks (Pahl and Beitz 2006; Ulrich and Eppinger 2008; French 1999; Pugh 1991) and used today as a general framework for engineering projects. It is often summarized as a sequence of design steps: an initial step to clarify the task, a second phase of conceptual design, a third of so-called "embodiment" and a last step of detailed design (see diagram below).

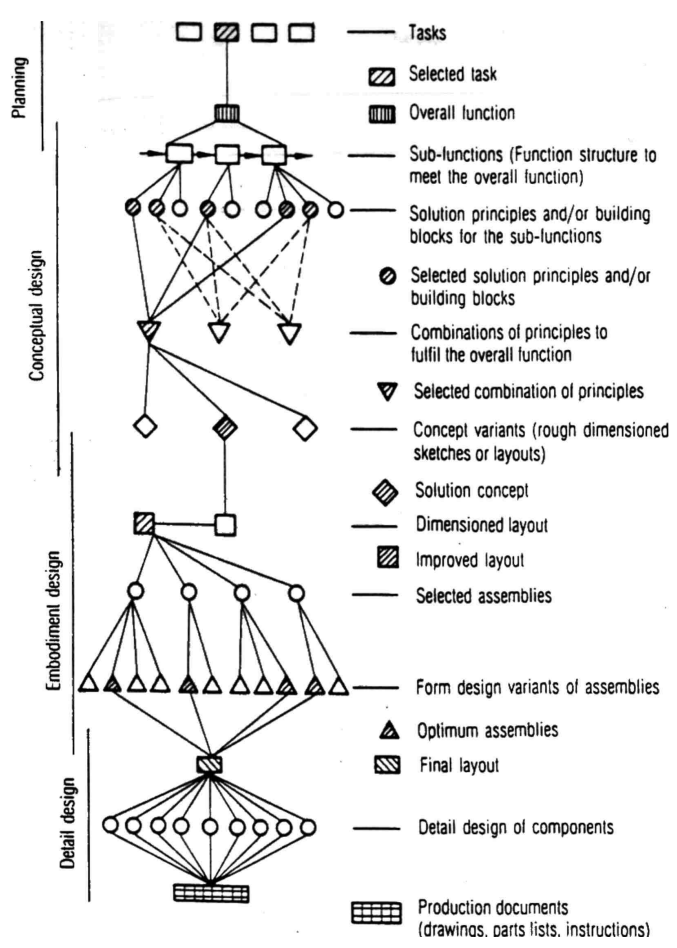

Figure 4: Systematic design according to Pahl \& Beitz (Pahl and Beitz 1977)

What are the origins and the formal model of SD? SD was born step by step between 1900 and the 1960s, following a number of criticisms of the ratio method (Heymann 2005). The theory tried to address two main criticisms:

1- The ratio method, still in use at the beginning of the $20^{\text {th }}$ century, was unable to take into account the regular progress in science and, more generally, the increased capacity for creating knowledge. This gave rise to a critical fixation: designers tended to reuse outdated, obsolete design rules.

2- Moreover, designers tended (and were even taught) to use existing machine elements to design complex assemblies. Design could be seen as a combination of existing elements that determined the layout, the architecture, the organization 
and even the technical principles to be used for an object. The attraction exercised by machine elements tended to reduce the exploration of new technical principles and new architectures.

In this context, SD can be seen as a method that reopens spaces for creativity, pushing the designers NOT to reuse existing knowledge but to explore new knowledge on technical principles and architectures, in a rigorous, efficient way.

\section{II.B.2- Principles of SD reasoning}

SD reasoning consists in refining the description of future, still unknown objects, following clear, rigorous steps to make use of and produce relevant knowledge.

1. In a given "design exercise" (Aufgabe), preliminary thinking (Vorüberlegung) helps determine the fundamental principle formulated in a few clear sentences. This fundamental principle is the "design core" (Wesenskern) that contains "all the possible solutions"

2. The "principles of work" (Arbeitsprinzipien) are then elaborated by combining elements of solutions including characteristic criteria (Konstruktionsgesichtpunkte or value criteria). These principles of work have three main characteristics: 1) they comprise elements of solutions, i.e. physical systems or particular partial functions, especially those required for any solution; 2) the elements of solutions are completed by characteristic features (Merkmale, value attributes) that serve to determine, to the greatest possible extent, the characteristics such as materials, processes, forms, energy sources, etc. and 3) the principles of work must also specify the forms of matching (Abhängigketisverhältnis, the relation of dependency) that link the functional elements to one another. For each element of solution there is a "residue" or "error", ie a distance remaining between what is "known" about the final solution and what has to be known to solve the design exercise.

3. By analyzing errors, the designers identify improved principles of work (verbesserte Arbeitsprinzipien).

4. They then define all the residual parameters, leading to a production project (Herstellunsunterlagen)

(see diagram below (Hansen 1955)).

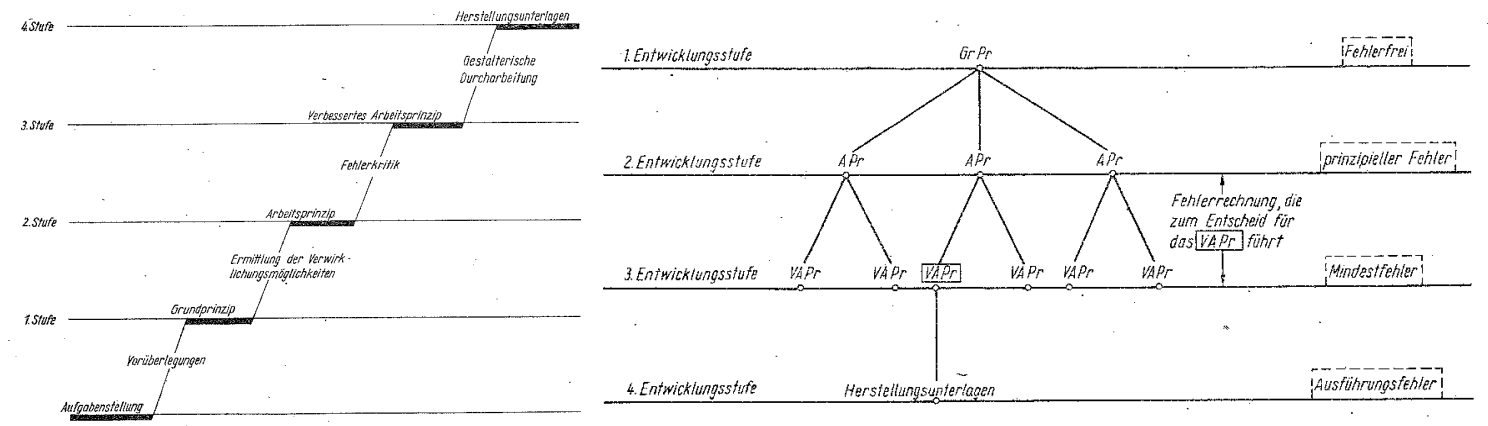

Figure 5: Basic diagram and process for systematic design (Hansen 1955)

This process tends to overcome precisely the above-mentioned fixations: 
1. The phase in which the Grundprinzip, or fundamental principle, is determined is original and the authors particularly stressed its importance: "Although such and such a solution has already emerged, it is important to clarify a fundamental principle. This step towards the abstract is needed to help find possibilities for new outputs, despite a lack of experience”, p. 10 (Hansen 1955). It is a way of overcoming the (precipitated) reuse of existing solutions.

2. The design process is divided into phases, each including work to acquire specific knowledge on existing things. The first stage encourages designers to learn about the specifications. Which ones are indispensible? Which can to be taken into account on an optional basis, possibly with extra costs, and which can be met as part of overall development, but not necessarily during the design exercise underway. The authors insisted on the fact that state of the art reviews should only be done at the second stage. If they are carried out too early, they can encourage designers to follow paths that, although they seem promising, may prevent them from exploring potentially even better solutions and put an end to opportunities for constant progress. Identifying a variety of alternatives improves the ability to find any "gaps" in the reporting of state of the art reviews and known solutions. The third stage implies an ability to evaluate the solutions' robustness, with a view to determining the possible variations (or in some cases anomalies) in the expected nominal behaviour. It also involves the ability to make calculations comparing the different principles of work that have been improved.

3. The authors underlined that the designers should avoid adding properties too quickly to the unknown object at each stage. Hence, the aim of the fundamental principle is to prevent designers from running to the drawing board as soon as the design exercise is launched. The principles of work (Arbeitsprinzip) (end of stage 2) can be defined using rough hand sketches only and do not require detailed technical drawings, although certain geometric interdependencies may require a scale drawing. The second stage, which is essentially physico-mathematic, should not be restricted either by considerations relating to materials.

\section{II.B.3-SD and design management}

This gives several insights about knowledge on design, design processes and design organization:

1- Regarding knowledge on design, SD aims to fight the fixation caused by existing design rules: it recommends the moment when design rules should be used and it supports the creation of new knowledge for expansion at the right time.

2- Regarding the compromise between convergence and divergence, SD organizes convergence by predefining the order in which the unknown object should be described. At each level, a specific language and a specific type of knowledge and knowledge production should be used: functional, conceptual, embodiment and detailed design. This hierarchy is also the way to maintain divergence in the process, since exploration is required at each language level.

3- Regarding design work division, SD enabled the complex division of labour found in contemporary engineering projects. The authors showed that complex machines can be designed using a process involving the systematic design of subunits and by ensuring the latters' integration by recursive loops. This type of reasoning enables project planning and V-cycles. 


\section{II.B.4- The consequences of SD for innovation}

The method, although apparently complex and abstract, was a great success. First at Zeiss, in the former GDR, where it was initially developed: "For small constructions, the method allows for savings of around 25\%; for more complex systems, adjustment times could be reduced from 3 months to 2 weeks." The method was then rapidly disseminated in the GDR, by the school in Ilmenau and by publications. The method was used both for company organization (defining the relations between research and development) (Hansen 1961) and for education (Hansen 1960).

It was also a success abroad. Whereas it is generally accepted that flows of knowledge have tended to move, overall, from the west to the east, many German historians believe that systematic construction was one of the few competencies that went from east to west (Heymann 2005). A small number of West German researchers were invited to the seminars in the GDR. In the Federal Republic of Germany, a similar rationalisation movement did not take place until the 1960s. When the labour crisis became a public crisis, two major seminars were organized on the theme of "the design bottleneck" (EngpassKonstruktion) in 1963-64, where the notions of Hansen et al. were explained and greeted with much interest. They were further transformed before the reference works on systematic design such as Pahl and Beitz' manual were published, but the latter contains many traces of the earlier works.

Contrary to the method of ratios, which required knowledge of the specific ratios for each class of object, SD is largely independent of the objects. This explains why the method was adopted in a range of very different fields, such as the automobile, IT, pharmaceuticals, building and microelectronics industries.

In the decades following its development by Rodenacker, Roth, Koller, Pahl and Beitz and later Hubka and Eder, the theory became widely used in the manuals, particularly in the Anglo-Saxon world once Pahl and Beitz' work had been translated by Ken Wallace. It gave rise to a certain number of debates. Albert Leyer led one of the most violent. In the 1960s and 70s and up to the 1983 International Conference on Engineering Design, Leyer, who was considered as a design genius, criticized the logic of the "scientisation" of the construction methods to the detriment of creativity. The debate does not seem to have been really clarified during this period: the systematic design manuals soon integrated "creativity techniques" (see the successive editions of Pahl and Beitz' works) and many authors like Pahl or Ehrlenspiel considered that it was sufficient to cater for Leyer's concern that creativity should be taken into account.

In the 1980s, empirical studies often revealed that the designers only rarely used formal frameworks explicitly. The famous author of a product development manual, Ehrlenspiel (Ehrlenspiel 1995), claimed that design reasoning is to a great extent unconscious. It appears that the theory is so deeply rooted in the organizations, particularly the product development organizations described by Ehrlenspiel, that it does not even require consciousness. Today, the formal framework of systematic design is so deeply embedded that the designers are mere cogs in the organization, who no longer even have an overall view or understanding of it, and in fact no longer need to. 


\section{II.C. Bauhaus}

\section{II.C.1- Fixed by clichés and limited perception}

A third historical moment in the creation of design theory took place in Weimar with the emergence of the Bauhaus. Bauhaus obviously does not appear as a direct leagacy of engineering design and the first stages of what we will be later called industrial design introduces problems and goals that were less considered in engineering design tradition, like simplification of uses, emotional values, semantic and symbolic value, etc... However these differences shouldn't hide the fact that there were strong theoretical principles in the Bauhaus approach. We will now analyse these principles and the way they help to deal with creativity issues.

Created by Walter Gropius, this school for artists and industrial designers "aimed to serve the modern development of housing, from the simplest domestic appliance to the whole dwelling" (Gropius 1925). It had a clear program: "A resolute acceptance of the living environment of machines and vehicles; the organic creation of objects following their own present-day laws, without embellishments or romantic adornment; a limitation to typical, basic forms and colours that are accessible to everybody; simplicity in quantity, with a sparing use of space, material, time and money" (Gropius 1925).

It led to the invention of an original teaching method and Itten, Klee and Kandinsky, who were in charge of the preliminary courses and the courses on form, developed a design theory for industrial designers. They were motivated by the idea of making students more creative. They did not consider creativity as a given talent; as Itten said: "imagination and creative ability must first of all be liberated and strengthened."

They identified several impediments or obstacles to creativity. Designers are fixed by common associations of attributes. Forms, materials, textures and meaning are too strongly, too deterministically, linked together. The "cliché" (a warm wood, a cold metal, etc.) is the main risk for designers. Itten proposed a theory of colours to fight against that fixation, to "liberate the study of colours' harmony from associations with forms." Klee developed new understandings of forms (form as movement, form as rhythm, form as music, form as a living body, etc.) to counterbalance the usual association between composition and the assembly of geometrical forms. As he explained, a circle is NOT the limit of a round shape, it is the result of the circular movement of a point; a round shape is the result of the circular movement of a segment (p. 176). Designing the structure of a painting is actually designing the movement of the eye of the "viewer" (p. 127) (Klee 1922).

Designers are also limited by their own perception and sensitivity. In Itten's view, the first reason for studying old masters was to improve perception. Oskar Schlemmer reported what happened during a study of Mathias Grünewald's Issenheim altarpiece (cited by Droste (Droste 2002), p. 28) : "Itten looked at his students' sketches then boomed: 'If you had even the slightest artistic sense you wouldn't draw in front of this sublime representation of tears, the tears of the world, you would sit down and burst out crying'. Having said that, he slammed the door." In 1921, Itten wrote the following about his students' studies: "Don't be discouraged if your copy doesn't look like the original. The more the picture really comes to life within you, the more perfect your reproduction will be, as it is an exact measure of the strength of what you have experienced. You live the work of art, it is reborn within you." A theory of contrast aims 
to open new creative worlds to students, not only in the sense of providing new means of expression but also of "improving perceptions" (Itten).

\section{II.C.2- Theories to disentangle and enable generative superimpositions}

Professors such as Itten, Klee and Kandinsky had a theoretical approach that enabled them to teach design, ie to teach this capacity to overcome fixations. As underlined by (Whitford 1984)(p.91), the need to teach led to the development of theories and not the contrary. As Itten wrote: "A theory of colour will help the students discover the expressive quality of colours and colour constrast." He added: "The objective law of form and colour helps to strengthen a person's powers and to expand his creative talents" (Itten 1975).

To illustrate the method, we can analyze the series of exercises proposed by Itten to learn about textures (Itten 1975). In a first phase, students were told to draw a lemon. Beginning by the representation of an object, Itten wanted the students to go from "the geometrical problems of form" to the "essence of the lemon in the drawing." It was an "unfixing" exercise, helping the students to avoid assimilating the object with a geometrical form.

In a second phase, the students were asked to touch several types of textures, to "improve their tactile assessment, their sense of touch." This was a learning phase in which students "sharpened observation and enhanced perception."

In a third phase, students built "texture montages in contrasting materials" (see picture below). During this exercise, students began to use textures as a means of design. The constraint (design only by contrasting textures) helped them to learn about textures (to explore the contrasting dimensions of different textures and improve their ability to distinguish between them). It also meant that they were able to explore the intrinsic generative power of textures, ie the superimposition of textures that should create something new: "roughly smooth", "gaseous fibrous", "dull shiny", "transparent opaque", etc.

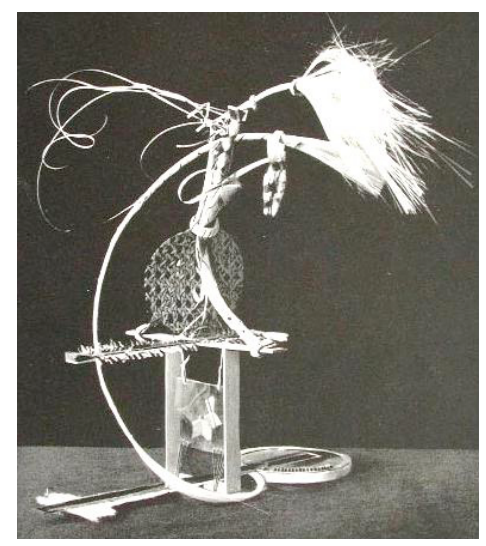

Figure 6: Texture montage exercise (Itten 1975)

The fourth phase could be qualified as "research". As the students were by then more sensitive to the variety of attributes of a texture, they could "go out" to find "rare textures in plants." It is interesting to underline that Itten did NOT begin with this phase, as he was conscious of the need to begin by strengthening their capacity to recognize new things, just as a botanical researcher has first to learn the plant classification 
system and discriminating features before being able to identify a new specimen. In particular, students were told to find new textures for a given material (see figure below in which all the textures are made from the same wood). Once again, this was an exercise to disentangle texture from other fixing facets, ie materials, in the case in point.

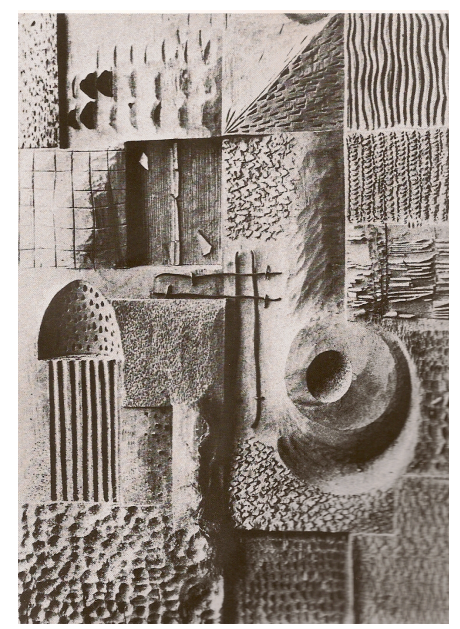

Figure 7: Several textures with the same material

The fifth phase consisted in representing textures. Itten stipulated that students had to represent "by heart", "from their personal sensation", to go from "imitation" to "interpretation". Instead of being an objective "representation", this exercise was intended as a design one, as students had to combine textures with their own personality. Just as phase 4 aimed at creating something new from the superimposition of contrasting textures, the idea in this phase was that the new should emerge from the superimposition of texture and the individual "heart". It was also designed to help improve sensitivity.

The sixth and last phase consisted in characterizing environmental phenomena as textures. For instance, the figure below shows a marketplace painted as a patchwork blanket. Itten urged students to use texture as an autonomous means of expression and not just a "constrained" ornament. By combining their enriched algebra of textures and the algebra of scenes, they could create new "textured scenes" that were more than the scenes and more than the textures. As Itten explained: "It stimulates the students to detach themselves from the natural subject, and search for and reproduce new formal relations"

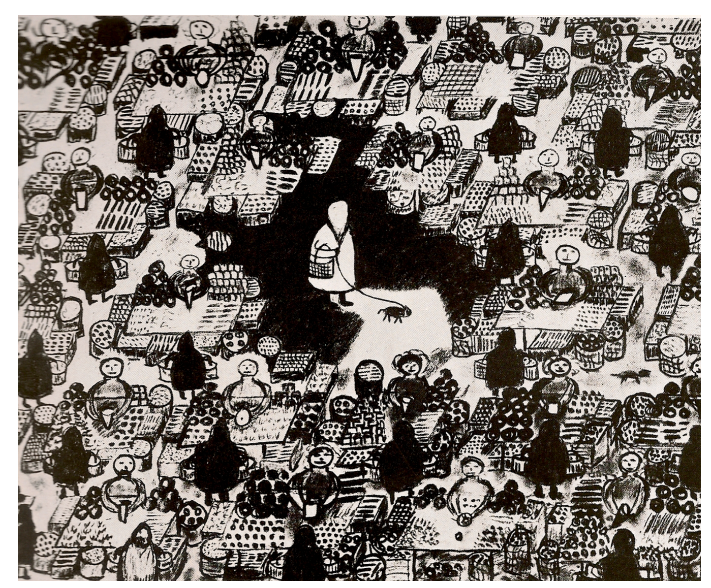

Figure 8: characterize environmental phenomena as textures 
It should be underlined that this process was more than a "descriptive" theory of textures, just as Redtenbacher's waterwheel design method was more than a theory of (existing) waterwheels. It was also a method for designing new textures and for using textures for expansion. It counterbalanced fixations due to "clichés" and limitations in perceptions by increasing the capacity to discriminate between textures (perception, descriptors of textures) and by increasing the generative power of textures.

\section{II.C.3- Bauhaus and innovation}

Although Bauhaus only lasted a short period of time (1919-1933) it had a great impact on industrial design. The school contributed to regenerating the grammar of objects in several fields (furniture, building, typography, consumer goods, etc.). As Whitford pointed out (p.115): "theoretical aspects of preliminary courses have had, curiously, an effect on what was produced in the workshops." In fact, the methods and theories developed in these courses were widely recognized and spread well beyond Bauhaus itself.
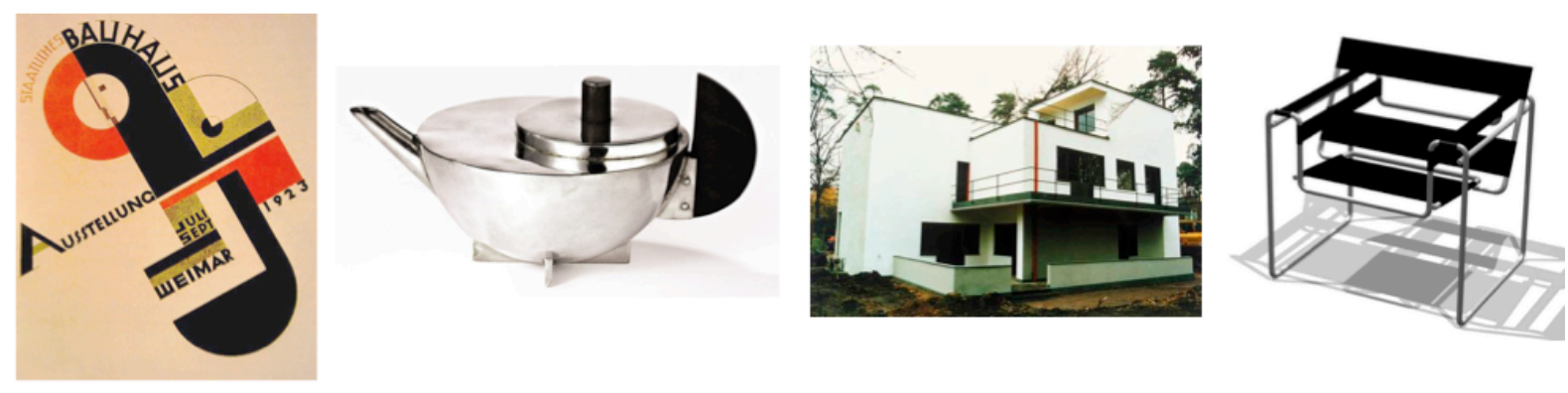

Figure 9: Some examples of the new grammar of forms generated at Bauhaus - some famous products (Marian Brand Tea Pot, Wassily Chair, Bauhaus building, Bauhaus poster)

The theories of design developed at Bauhaus are also a great source of inspiration for knowledge management, processes and organization for innovation:

1- Regarding knowledge in design, the Bauhaus design theories are based on the notion that improved knowledge of textures, materials, forms, colours, constrasts etc. helps to overcome "clichés": it disentangles the mechanical, unconscious associations between forms, colours, materials, etc. When the mechanical relationship is broken, then superimpositions of attributes support creative expansions.

2- Regarding the compromise between convergence and divergence, the theories favour synthesis and the creation of an "organism" (Klee 1922). In that sense, there is convergence towards a final product. Divergence comes from the multiple explorations and, above all, from the effect of superimposition: each new "layer" (a texture on a form, a material with a texture, etc.) creates potential divergence and yet the added layer can still be considered as a convergence towards a final "organism". The aggregation of "layers" is therefore both a divergent and convergent process.

3- Regarding organization, the theories and the Bauhaus organization itself provide interesting indications, with two striking features. First, the future designers were taught to work together "to compare their work and their creative power." 
This reinforced a form of collective control of creativity (by assessments, comparisons) inside the creative team. Second, Bauhaus directors (in particular Walter Gropius) insisted on the "program": combine "art and technique", work on "industrial products" (instead of combining art and craft, as indicated in the initial 1919 program). This second feature exemplifies strong leadership, not based on prescribed "projects" and "vision" but rather on the designation of a new area for imagination and expansion. Somewhere between the two extremes of the autonomous creator and of administrated innovation, mutually controlled, creative teams and the inspiring, stimulating leader appeared.

4- We should note that fixations caused by the Bauhaus design theory have also recently been identified. For instance, in the Bauhaus framework it is difficult to deal with new objects such as perfumes, services or web interfaces. More generally, the proposed theories have a fixation effect (in terms of colour, texture, material, etc.).

\section{Part 3: research proposals, discussion on the recent design theories and further research}

\section{III.A. Main results}

The analysis of the historical emergence of past design theories reveals an interesting interplay between creativity issues and design theory. Two main propositions emerge from this history:

P1: Creativity issues are symptoms of the limits of existing design theories. They evolve over time.

In the 1850s, the creativity issue concerned fixation by existing, already designed objects; in the first half of the $20^{\text {th }}$ century, the creativity issue concerned fixation by existing design rules and machine elements, leading to the non-relevant reuse of existing knowledge; in the 1920s at the Bauhaus, the creativity issue concerned "clichés" and the limited capacity for perception.

P2: Design theories emerge to overcome contemporary fixations and extend generative capacities.

In the 1850s, the ratio method helped to use relevant rules for designing contextsensitive products; in the 1950s, systematic design proposed a design method based on pre-ordered languages (functional, conceptual, embodiment, detailed design) to enable divergence and the production of knowledge at the right moment and hence propose constantly improved products. In the 1920s, the Bauhaus theorists renewed the theories of forms, colours and materials to enable generative superimpositions.

These design theories also provide interesting ways to deal with design capability management.

P3: Design theories invent new ways to use knowledge for design. 
Each of these design theories provides sophisticated and original ways to make use of knowledge while overcoming knowledge fixation. Redtenbacher's ratio method counterbalanced the tendency to use the knowledge on existing objects by creating a "context-sensitive" algorithm based on stabilized models of the object, enabling designers to use the right knowledge at the right moment. German systematic design manages knowledge creation in such a way as to prevent designers from continuing to reuse obsolete design rules. It is based on wide-ranging knowledge maps, which help identify the "gaps" and thus focus creativity where it is relevant. The Bauhaus theories built enriched models of materials, forms, colours and contrasts, to help disentangle them and support generative superimpositions.

P4: Design theories invent new ways of combining divergent thinking and convergent thinking in design processes

Although Redtenbacher's ratio method was highly convergent, it remained divergent at well-identified stages. In German systematic design, convergence is created by the progressive instantiation of pre-ordered languages of the objects, each new language also being a step involving temporary divergence. In the Bauhaus theories, the emergence of the "organism" resulted from superimpositions of dimensions (forms, material, colour, etc.) which were also opportunities for divergence.

Finally design theories could have helped to invent new ways of combining autinimous creative teams and control. Redtenbacher's ratio method led to a distinction between the rule-maker and the rule-user (initially the professor and the technician). In German systematic design, a distinction emerged between the project team with a clear target and a clear framework and the engineering department, in charge of controlling the reuse and production of knowledge. Bauhaus invented a form of "mutually assessed" collective creativity, in interaction with inspiring leadership, based on certain constraints ("use industrial processes and design rules") and the designation of expansion areas ("modern housing").

We summarize these results in the table below.

\begin{tabular}{|c|c|c|c|c|c|}
\hline $\begin{array}{l}\text { Creativity } \\
\text { issues }\end{array}$ & $\begin{array}{l}\text { Design theory - } \\
\text { formal model of } \\
\text { design } \\
\text { reasoning }\end{array}$ & $\begin{array}{l}\text { Method to deal } \\
\text { with knowledge } \\
\text { in design } \\
\text { (creativity } \\
\text { enabler / } \\
\text { fixation) }\end{array}$ & $\begin{array}{l}\text { Design process } \\
\text { (convergence } \\
\text { vs divergence) }\end{array}$ & $\begin{array}{l}\text { Design } \\
\text { organization } \\
\text { (creative team } \\
\text { vs control) }\end{array}$ & $\begin{array}{l}\text { Type of } \\
\text { innovation } \\
\text { output \& } \\
\text { type of } \\
\text { new } \\
\text { fixation }\end{array}$ \\
\hline $\begin{array}{l}\text { Fixed by } \\
\text { existing } \\
\text { products }\end{array}$ & $\begin{array}{l}\text { Ratio method } \\
\text { (Redtenbacher, } \\
\text { 1850s). } \\
\text { Parametric } \\
\text { design: } \\
\text { instantiate a } \\
\text { parametric } \\
\text { model, based } \\
\text { on context- } \\
\text { sensitive data }\end{array}$ & $\begin{array}{l}\text { A series of } \\
\text { design rules, } \\
\text { based on a } \\
\text { stabilized, } \\
\text { synthetic model } \\
\text { of the object }\end{array}$ & $\begin{array}{l}\text { Context } \\
\text { sensitive } \\
\text { algorithm } \\
\text { ensuring } \\
\text { convergence } \\
\text { towards a } \\
\text { satisfying } \\
\text { solution and } \\
\text { divergence at } \\
\text { critical moments }\end{array}$ & $\begin{array}{l}\text { Dividing work } \\
\text { between rule- } \\
\text { maker and rule- } \\
\text { user }\end{array}$ & $\begin{array}{l}\text { Adapted, } \\
\text { varied } \\
\text { products. } \\
\text { Fixation = } \\
\text { fixed by } \\
\text { existing } \\
\text { models of } \\
\text { objects }\end{array}$ \\
\hline $\begin{array}{l}\text { Fixed by the } \\
\text { reuse of } \\
\text { non-relevant }\end{array}$ & $\begin{array}{l}\text { Systematic } \\
\text { Design } \\
\text { (Hansen et al. } \\
\text { 1950s, Pahl \& }\end{array}$ & $\begin{array}{l}\text { Libraries and } \\
\text { catalogs of } \\
\text { product } \\
\text { modules and }\end{array}$ & $\begin{array}{l}\text { Convergence } \\
\text { and divergence } \\
\text { by pre-ordered } \\
\text { languages to }\end{array}$ & $\begin{array}{l}\text { Project leader } \\
\text { framed by a } \\
\text { clear, specified } \\
\text { target; }\end{array}$ & $\begin{array}{l}\text { Variety, } \\
\text { continuous } \\
\text { innovation, } \\
\text { continuous }\end{array}$ \\
\hline
\end{tabular}




\begin{tabular}{|c|c|c|c|c|c|}
\hline design rules & $\begin{array}{l}\text { Beitz 1970s). } \\
\text { Reduce the } \\
\text { unknown to a } \\
\text { minimum } \\
\text { (residue) by } \\
\text { using the } \\
\text { known as much } \\
\text { as possible } \\
\text { (approximation } \\
\text { of the unknown } \\
\text { through the } \\
\text { known) }\end{array}$ & $\begin{array}{l}\text { design } \\
\text { principles. } \\
\text { Knowledge } \\
\text { creation at well- } \\
\text { identified steps; } \\
\text { identify "holes" } \\
\text { (residue) to } \\
\text { focus creativity } \\
\text { where it is } \\
\text { relevant }\end{array}$ & $\begin{array}{l}\text { create the } \\
\text { object }\end{array}$ & $\begin{array}{l}\text { engineering } \\
\text { department } \\
\text { heads control } \\
\text { the relevant use } \\
\text { and creation of } \\
\text { rules }\end{array}$ & $\begin{array}{l}\text { knowledge } \\
\text { production } \\
\text { Fixation = } \\
\text { limited } \\
\text { language } \\
\text { of the } \\
\text { object, no } \\
\text { capacity to } \\
\text { regenerate } \\
\text { the } \\
\text { languages. }\end{array}$ \\
\hline $\begin{array}{l}\text { Fixed by } \\
\text { "cliché" }\end{array}$ & $\begin{array}{l}\text { Bauhaus } \\
\text { school (Itten, } \\
\text { Klee, etc. } \\
\text { 1920s) } \\
\text { Generative } \\
\text { superimposition } \\
\text { of different } \\
\text { perspectives on } \\
\text { the object }\end{array}$ & $\begin{array}{l}\text { Abstract and } \\
\text { practical } \\
\text { knowledge (on } \\
\text { form, material, } \\
\text { texture, colour, } \\
\text { etc.: theory, } \\
\text { value, variety, } \\
\text { transformation } \\
\text { procedures, } \\
\text { etc.) to } \\
\text { disentangle } \\
\text { clichés. }\end{array}$ & $\begin{array}{l}\text { Convergence } \\
\text { and divergence } \\
\text { by } \\
\text { superimposition }\end{array}$ & $\begin{array}{l}\text { Mutual } \\
\text { assessment of a } \\
\text { group of } \\
\text { creators; } \\
\text { inspiring leader } \\
\text { designating } \\
\text { areas of } \\
\text { expansions }\end{array}$ & $\begin{array}{l}\text { New } \\
\text { grammar } \\
\text { of objects } \\
\text { Fixation = } \\
\text { limited to } \\
\text { theories of } \\
\text { colouars, } \\
\text { shape and } \\
\text { texture. }\end{array}$ \\
\hline
\end{tabular}

Table 1: Summary of the main results

It should be underlined that even if engineering design and industrial design obvisouly deal with different types of goals, we find a common pattern: in each case design theory helps to deal with creativity issues.

\section{III.B. Design theory and creativity today? Testing our framework}

These propositions can be tested by looking at recent advances in creativity studies and design theories, two fields of research that have grown very fast in the last few decades. As a comprehensive study of the advances is out of the scope of this paper we would simply like to underline what our proposals lead us to examine in the literature.

Following proposition P1, our question is: what new forms of fixations have been identified in the literature? Prolonging the seminal works and experiments of Smith et al. (Smith et al. 1993) and (Jansson and Smith 1991) on fixation by recently activated knowledge, recent studies have identified several types of fixations: fixation by the representations of things (Ward 1994), fixation by knowledge that is too "contaminated by the specific goal and task" (Finke 1990), fixation by the limited capacity to use knowledge that is a long way from the task (difficulty in using metaphors, in connecting with different types of knowledge) (Burkhardt and Lubart 2010), fixation by emotions (Zenasni and Lubart 2009), fixation by images and metaphors (Chrysikou and Weisberg 2005), fixation by organizational and social relationship in firms that are not "creativityexperts" (Stewart and Stasser 1995; Sutton and Hargadon 1996). These newly identified forms could well be the new challenges for design theories. 
Proposition P2 invites us to analyze how recent design theories propose to overcome these new fixation effects and extend generative capacity. We can take a brief look at three theories or methods: TRIZ, C-K theory and "infused design". TRIZ (or ASIT) aims to help users overcome fixation caused by relying on usual solutions to a problem; it proposes wide databases (wider than the classic libraries of systematic design) and a smart "browser", the matrix of contradictions, to find "creative" solution principles to problems (Altshuller 1984; Rasovska et al. 2009; Reich et al. 2010). C-K theory (Hatchuel and Weil 2003; Hatchuel and Weil 2009) helps to overcome fixation by the representation of things. It supports the revision of object identities by the dual expansion of knowledge and concepts. It has also been proved relevant in counterbalancing several of the fixation effects listed above (Hatchuel et al. 2011b). Infused design (Shai and Reich 2004a, b) supports rigorous relationships between different scientific objects (trusses, mechanics, cinematics, etc.) to increase designers' capacity to make use of very heterogeneous disciplines (Shai et al. 2009), hence overcoming fixation by usual competences and skills. It has been shown that it helps to identify "gaps" in certain disciplines (eg relative velocity in cinematics has no equivalent in mechanics) and has led to the creation of new scientific objects (the face force) (Shai et al. 2009). It has also been shown that $\mathrm{C}-\mathrm{K}$ theory and infused design increase generative capacities (Hatchuel et al. 2011a). Hence, these design theories can address some of the fixations listed above.

Do these theories suggest new ways of dealing with knowledge for design (P3)? TRIZ proposes new ways of "browsing" for technologies; C-K theory supports rule-breaking in the knowledge base, the expansion of knowledge driven by the imagination, the creation of new definitions of things, as well as "knowledge re-ordering" required for the "preservation of meaning" in the new world and new forms of absorptive capacity based on structures of the unknown (Hatchuel and Weil 2007; Le Masson et al. 2011). Infused design aims to identify "gaps" in knowledge bases and to "fill" these gaps by using "complementary" knowledge for design (Shai et al. 2009).

Do these theories suggest new ways of dealing with convergence and divergence in design processes (P4)? Methods inspired by TRIZ, such as ASIT, maintain strong convergence, in particular by making a "closed world assumption" that avoids too many explorations and tends to focus on the minimal "break" out of the "closed world" (Moehrle 2005; Reich et al. 2010). Processes derived by C-K theory are characterized by interdependent exploratory design paths. Each new design step can provoke unexpected expansions and these expansions can open new, unexpected paths for convergence in a growing tree of paths (Elmquist and Segrestin 2007; Elmquist and Le Masson 2009). Infused design suggests a distinction between fast convergence, using rigorous relations between disciplinary models, and divergence, to explore the "gaps" revealed by this conformity.

These theories and methods can also inspire or support new forms of design organization for innovation (P5), balancing creation and control. The TRIZ method supports the intervention of "creative commandos" called on by the traditional project organizations to solve "extraordinary" problems that unexpectedly emerge during the project process (Engwall and Svensson 2001). C-K theory has helped to characterize new forms of organizations, when firms shift from R\&D to RID, organizing departments dedicated to innovative design (Le Masson et al. 2010). Two levels can be clearly distinguished in these design-oriented organizations (DO2): design spaces, where 
focused explorations and knowledge acquisition take place, and value management, which designates and launches design spaces, coordinates explorations, manages interdependency and repetitions, and gradually elaborates a design strategy that simultaneously and synergistically accelerates innovation outputs (convergence) and enables more and more disruptive explorations (Hatchuel et al. 2005). Infused design leads to new forms of interdisciplinarity, in which rigorous relations between disciplines encourages designers to be more creative and creative explorations enrich the different scientific discplines.

\section{III.C. Further research}

Our study on the historical interplay between creativity and design theory is still exploratory. It shows 1 ) that there is a direct relationship between design theory and creativity and 2) that, as means of overcoming fixations, design theories open new paths for reflecting on innovation management. This requires further research, on at least three topics:

- We identified fixation effects as one reason for changing from one theory to another. However, the new possibilities offered by formal theories (advances in logic, in mathematics, etc.) can also play a role, as is the case in the more recent theories. More generally, what factors drive the change to a new design theory?

- Is there a specific trend in the evolution of design theories? In our historical study, we see clear progress in the level of abstraction: from Redtenbacher's method of ratios to SD, and then to contemporary design theories, the theory has become more and more independent of the objects; it overcomes more and more fixations and has gained in generativity. These trends have also been analyzed with respect to the more recent, formal, design theory, showing that increases in generativity and robustness might be two specific features of the advances of design theories (Hatchuel et al. 2011a). These trends call for further research.

- We have only briefly described the relations between fixation, design theories, design methods and new fixations. More detailed analyses are required: what are the processes that lead from creativity studies to design theories? What are the processes that help establish new design practices based on new design theories? What is the relationship between these new practices and the identification of new fixations?

This leads to a new framework to analyze different forms of design capabilities. For each form, our framework consists in:

- identifying creativity issues, ie types of fixation, which have to be addressed

- analyzing design theories addressing these fixations and the related design capabilities, ie the way to deal with knowledge, processes and organization

- clarifying the types of performance (and measures) to be reached by the different forms and the type of fixation that they might cause.

This work also paves the way to new forms of research on innovation. The use of design theories could help to propose: 
1) New frameworks for comparative studies, eg a study of different types of fixation and different types of "innovation" over time. The identification of new fixations might call for new design theories, whereas new design theories might cause new fixations that will be identified by creativity studies. What are the future fixations of the newlyemerging design theories?

2) New frameworks for analyzing data: recent studies have precisely used design theories to analyze absorptive capacity in radical innovation situations (Le Masson et al. 2011), front-end management in drug design (Elmquist and Segrestin 2007), project failure or success (Elmquist and Le Masson 2009) and exploration and exploitation in innovation (Gobbo and Olsson 2010).

3) New frameworks for generating data: through experimentations (Agogué et al. 2011; Savanovic and Zeiler 2009) and in research-industry partnerships (Gillier et al. 2010)...

4) New frameworks for reinterpreting historical data about famous inventors or famous engineering companies.

Finally, by encouraging the interplay between creativity and design theory, by focusing creativity studies on the limits of existing design theories, by supporting the development of new design theories to overcome fixation effects, research on creativity and design theory can make a precious contribution to the invention of new forms of innovation management.

\section{References}

Agogué M, Cassotti M, Kazakçi A (2011) The Impact of Examples on Creative Design: Explaining Fixation and Stimulation Effects. Paper presented at the International Conference on Engineering Design, ICED'11, Technical University of Denmark,

Alexander C (1964) Notes on the Synthesis of Form. 15th printing, 1999 edn. Harvard University Press, Cambridge, MA

Alexander C (1971) The State of the Art in Design Methods. DMG Newsletter 5 (3):3-7.

Altshuller GS (1984) Creativity as an exact science: the theory of the solution of inventive problems (trans: Williams A). Studies in Cybernetics: 5. Gordon and Breach Science Publishers,

Amabile TM (1998) How to kill creativity. Harvard Business Review september-October 1998:77-87.

Amabile TM, Conti R, Coon H, Lazenby J, Herron M (1996) Assessing the Work Environment for Creativity. Academy of Management Journal 39:1154-1184.

Anschütz F, Fritsch M, Höhne G, Langbein P, Mehlberg H, Otte V (1969) Beiträge zum konstruktiven Entwicklungsprozess. Ilmenau

Archer LB (1965) Systematic Method for Designers. Council of Industrial Design, London

Basadur M, Gelade GA (2006) The Role of Knowledge Management in the Innovation Process. Creativity and Innovation Management 15 (1):45-62.

Brown SL, Eisenhardt KM (1997) The Art of Continuous Change : Linking Complexity Theory and Time-paced Evolution in Relentlessly Shifting Organizations. Administrative Science Quarterly 42 (1997):1-34. 
Burkhardt J-M, Lubart T (2010) Creativity in the Age of Emerging Technology: Some Issues and Perspectives in 2010. Creativity and Innovation Management 19 (2):160-166.

Chrysikou EG, Weisberg RW (2005) Following the Wrong Footsteps: Fixation Effects of Pictorial Examples in a Design Problem-Solving Task. Journal of Experimental Psychology: Learning, Memory and Cognition 31:1134-1148.

Cohen WM, Levinthal DA (1990) Absorptive Capacity: A New Perspective on Learning and Innovation. Administrative Science Quarterly 35 (1990):128-152.

Cropley A (2006) In Praise of Convergent Thinking. Creativity Research Journal 18 (3):391-404.

Cross N (2006) Forty years of design research (presidential address). Paper presented at the 2006 Design Research Society International Conference, Lisbon, 1 November 2006

Dorst K (2006) Design Problems and Design Paradoxes. Design Issues 22 (3):4-17.

Droste M (2002) Bauhaus 1919-1933. Taschen, Köln

Dym CL, Agogino AM, Eris O, Frey D, Leifer LJ (2005) Engineering Design Thinking, Teaching, and Learning. Journal of Engineering Education January 2005:103-120.

Ehrlenspiel K (1995) Intégrierte Produktentwicklung. Methoden für Prozessorganisation, Produkterstellung und Konstruktion. Carl Hanser Verlag, München, Wien

Elmquist M, Le Masson P (2009) The value of a 'failed' R\&D project: an emerging evaluation framework for building innovative capabilities. R\&D Management 39 (2):136-152.

Elmquist M, Segrestin B (2007) Towards a new logic for Front End Management: from drug discovery to drug design in pharmaceutical R\&D. Journal of Creativity and Innovation Management 16 (2):106-120.

Engelmeyer PKv (1895) Was ist eine Erfindung? Civilingenieur 41:282-300.

Engwall M, Svensson C (2001) Cheetah Teams. Harvard Business Review January 2001:20-21.

Eppinger S (2011) The Fundamental Challenge of Product Design. Journal of product innovation management 28 (3):399-400.

Eris $O$ (2004) Effective Inquiry for Innovative Engineering design. Kluwer Academic Publisher, Boston

Finke RA (1990) Creative Imagery: Discoveries and inventions in visualization. Erlbaum, Hillsdale, NJ

French M (1999) Conceptual Design for Engineers. 3rd edn. Springer, London

Gillier T, Piat G, Roussel B, Truchot P (2010) Managing Innovation Fields in a CrossIndustry Exploratory Partnership with C-K Design Theory. Journal of product innovation management 27 (6):883-896.

Gobbo JAJ, Olsson A (2010) The transformation between exploration and exploitation applied to inventors of packaging innovations. Technovation 30:322-331.

Gordon WJ (1961) Synectics: The Development of Creative Capacity. Harper \& Row, New York

Gropius W (1925) Neue Bauhauswerkstätten.

Guilford JP (1950) Creativity. American Psychologist 3:444-454.

Hansen F (1955) Konstruktionssytematik, eine Arbeitsweise für fortschrittliche Konstrukteure. VEB Verlag Technik, Berlin

Hansen F (1960) Konstruktionssystematik, ein neuer Weg zur Ingenieurerziehung. Feingerätetechnik 1960:44-51. 
Hansen F (1961) Grenzen und Wirkungsbereich der Konstruktionssytematik bei Forschungs- und Entwicklungsaufgabe. Feingerätetechnik 1961 (10):452-460.

Hargadon A, Sutton RI (1997) Technology Brokering and Innovation in a Product Design Firm. Administrative Science Quarterly 42 (4):716-749.

Hatchuel A (2002) Towards Design Theory and expandable rationality: the unfinished program of Herbert Simon. Journal of Management and Governance 5 (3-4):260273.

Hatchuel A, Glise H (2003) Rebuilding Management, A Historial Perspective. In: Adler N, Shani ABR, Styhre A (eds) Collaborative Research in Organizations, Foundations for Learning, Change, and Theoretical Development. pp 5-22

Hatchuel A, Le Masson P, Reich Y, Weil B (2011a) A systematic approach to design theories using generativeness and robustness. In: International Conference on Engineering Design, ICED11, Technical University of Denmark, 2011a. p 12

Hatchuel A, Le Masson P, Weil B (2005) The Development of Science-Based Products: Managing by Design Spaces. Creativity and Innovation Management 14 (4):345354.

Hatchuel A, Le Masson P, Weil B (2011b) Teaching Innovative Design Reasoning: How C$\mathrm{K}$ Theory Can Help to Overcome Fixation Effect. Artificial Intelligence for Engineering Design, Analysis and Manufacturing 25 (1):77-92.

Hatchuel A, Weil B (2003) A new approach to innovative design: an introduction to C-K theory. In: ICED'03, August 2003, Stockholm, Sweden, 2003. p 14

Hatchuel A, Weil B (2007) Design as Forcing: deepening the foundations of C-K theory. In: International Conference on Engineering Design, Paris, 2007. p 12

Hatchuel A, Weil B (2009) C-K design theory: an advanced formulation. Research in Engineering Design 19:181-192.

Heymann M (2005) "Kunst" und Wissenchsaft in der Technik des 20. Jahrhunderts. Zur Geschichte der Konstruktionswissenschaft. Chronos Verlag, Zürich

Itten J (1975) Design and Form, the Basic Course at the Bauhaus and Later. Revised edition (first edition1963) edn. John Wiley and Sons, Inc., London

Jansson DG, Smith SM (1991) Design Fixation. Design Studies 12 (1):3-11.

Kelley D (2009) Adaptation and Organizational Connectedness in Corporate Radical Innovation Programs*. Journal of product innovation management 26 (5):487501.

Klee P (1922) Beiträge zur bildnerischen Formlehre ('contribution to a pictorial theory of form', part of Klee 1921-2 lectures at the Bauhaus). Weimar

Koen P, Ajamian G, Burkart R, Clamen A, Davidson J, D'Amore R, Elkins C, Herald K, Incorvia M, Johnson A, Karol R, Seibert R, Slavejkov A, Wagner K (2001) Providing Clarity and a Common Language to the "Fuzzy Front End". Research/Technology Management 44 (2):pp. 46-56.

König W (1999) Künstler und Strichezieher. Konstruktions- und Technikkulturen im deutschen, britischen, amerikanischen und französischen Maschinenbau zwischen 1850 und 1930, vol 1287. Suhrkamp Taschenbuch Wissenschaft. Suhrkamp Verlag, Frankfurt am Main

Laakso M, Hassi L (2011) Design Thinking in the management discourse: defining the elements of the concept. Paper presented at the International Product Development Management Conference, Delft,

Lane PJ, Koka BR, Pathak S (2006) The reification of absorptive capacity: a critical review and rejuvenation of the construct. Academy of Management Review 31 (4):833-863. 
Le Masson P, Cogez P, Felk Y, Weil B (2011) Revisiting Absorptive Capacity with a Design Perspective. International Journal of Knowledge Management Studies.

Le Masson P, Weil B, Hatchuel A (2010) Strategic Management of Design and Innovation. Cambridge University Press, Cambridge

Leonard-Barton D (1992) Core Capabilities and Core Rigidities: A Paradox in Managing New Product Development. Strategic Management Journal 13:111-125.

Lindemann U (2011) Creative Engineering: which role for design theory? In: Design theory, Paris, 2011.

Loch CL, De Meyer A, Pich MT (2006) Managing the Unknown. John Wiley \& Sons, Hoboken, NJ

MacCormack A, Verganti R, Iansiti M (2001) Developing Products on "Internet Time": The Anatomy of Flexible Development Process. Management Science 47 (1):133150.

Moehrle MG (2005) What is TRIZ? From Conceptual Basics to a Framework for Research. Creativity and Innovation Management 14 (1):3-13.

O'Connor GC (2008) Major Innovation as a Dynamic Capability: A Systems Approach. Journal of product innovation management 25:313-330.

Osborn AF (1953) Applied Imagination: Principles and Procedures of Creative Problem Solving. First edition edn. Charles Scribner's sons, New York

Osborn AF (1957) Applied Imagination. First edition edn. Charles Scribner, New York

Pahl G, Beitz W (1977) Konstruktionslehre (English title: engineering design) (trans: Arnold Pomerans KW). Springer Verlag, English edition: The Design Council, Heidelberg, English edition: London

Pahl G, Beitz W (2006) Engineering design, a systematic approach (trans: Wallace K, Blessing L, Bauert F). Springer, Berlin

Paulus PB, Brown VR (2007) Toward More Creative and Innovative group Idea Generation: A Cognitive-Social-Motivational Perspective of Brainstorming. Social Personality Psychology Compass 1 (1):248-265.

Paulus PB, Yang H-C (2000) Idea Generation in Groups: A Basis for Creativity in Organizations. Organizational Behavior and Human Decision Processes 82 (1):76-87.

Poncelet J-V (1827) Mémoire sur les roues hydrauliques à aubes courbes mues par dessous, suivi d'expériences sur les effets mécaniques de ces roues, nouvelle édition revue et corrigée et augmentée d'un second mémoire sur des expériences en grand relatices à la nouvelle roue contenant une instruction pratique sur la manière de procéder à son établissement. 2ème édition edn. Thiel, Metz

Pugh S (1991) Total Design. Integrated Methods fo Successful Product Engineering. Prentice Hall, Pearson Education., Harlow, England

Rasovska I, Dubois S, De Guio R (2009) Mechanisms of model change in optimization and inventive problem solving methods. In: International Conference on Engineering Design, ICED'09, 24-27 August 2009, Stanford CA, 2009.

Redtenbacher F (1852a) Prinzipien der Mechanik und des Maschinenbaus. Bassermann, Mannheim

Redtenbacher F (1852b) Resultate für den Maschinenbau. 2ème édition edn. Friedrich Bassermannn,

Redtenbacher F (1858) Theorie und Bau der Wasser-Räder. 2ème édition (1ère édition 1846) edn. Bassermann, Mannheim 
Reich Y, Hatchuel A, Shai O, Subrahmanian E (2010) A Theoretical Analysis of Creativity Methods in Engineering Design: Casting ASIT within C-K Theory Journal of Engineering Design:1-22.

Reid SE, De Brentani U (2004) The Fuzzy Front End of New Product Development for Discontinuous Innovations: A Theoretical Model. Journal of product innovation management 21 (3):170-184.

Rittel HWJ, Webber MM (1972) Dilemnas in a General Theory of Planning. University of California at Berkely, Berkeley

Rodenacker WG (1970) Methodisches Konstruieren. Konstruktionsbücher. Springer Verlag, Berlin

Roth K (1982) Konstruieren mit Konstruktionskatalogen. Springer Verlag, Berlin

Savanovic P, Zeiler W (2009) Integral Design Method for Conceptual Building Design. In: International Conference on Engineering Design, 24-27 August 2009, Stanford CA, 2009.

Seidel VP (2007) Concept Shifting and the Radical Product Development Process. Journal of product innovation management 24 (6):522-533.

Shai 0, Reich Y (2004a) Infused Design: I Theory. Research in Engineering Design 15 (2):93-107.

Shai 0, Reich Y (2004b) Infused Design: II Practice. Research in Engineering Design 15 (2):108-121.

Shai O, Reich Y, Hatchuel A, Subrahmanian E (2009) Creativity Theories and Scientific Discovery: a Study of C-K Theory and Infused Design. In: International Conference on Engineering Design, ICED'09, 24-27 August 2009, Stanford CA, 2009.

Simon HA (1969) The Sciences of the Artificial. M.I.T. Press, Cambridge, MA, USA

Smeaton J (1810) Recherches expérimentales sur l'eau et le vent, considérés comme forces motrices, applicables aux moulins et autres machines à mouvement circulaire, suivies d'expériences sur la transmission du mouvement et la collision des corps (trans: Girard PS). Edition française edn. Courcier, Paris

Smith SM, Ward TB, Schumacher JS (1993) Constraining effects of examples in a creative generation task. Memory and Cognition 21:837-845.

Stewart DD, Stasser G (1995) Expert role assignment and information sampling during collective recall and and decision-making. Journal of Personality and Social Psychology 69:619-628.

Sutton RI, Hargadon A (1996) Brainstorming Groups in Context: Effectiveness in a Product Design Firm. Administrative Science Quarterly 41 (4):685-718.

Swan KS, Luchs M (2011) From the Special Issue Editors: Product Design Research and Practice: Past, Present and Future. Journal of product innovation management 28 (3):321-326.

Tushman ML, O'Reilly III CA (1996) Ambidextrous Organizations: Managing Evolutionary and Revolutionary Change. California Management Review 38 (4):8-30.

Ulrich KT, Eppinger SD (2008) Product Design and Development. 4th edn. Mc Graw Hill,

Verganti R (2008) Design, Meanings, and Radical Innovation: A Metamodel and a Research Agenda. Journal of product innovation management 25 (5):436-456.

Ward TB (1994) Structured Imagination: The Role of Category Structure in Exemplar Generation. Cognitive Psychology 27:1-40. 
Weisberg RW (1999) creativity and Knowledge: A Challenge to Theories. In: Sternberg RJ (ed) Handbook of Creativity. Cambridge University Press, cambridge, pp 226250

Whitford F (1984) Bauhaus. world of art. Thames \& Hudson, London

Zan L (2005) Future Directions from the Past: Management and Accounting Discourse in Historical Perspective. Advances in Strategic Management 22:457-489.

Zenasni F, Lubart T (2009) Emotion related-traits moderate the impact of emotional state on create potential. Journal of Individual Differences 29 (3):157-167. 